\title{
Managing Biodiversity: Impacts of Legal Protection in Mountain Forests of the Himalayas
}

\author{
Inger Elisabeth Måren 1,* (D) and Lila Nath Sharma 2 (iD \\ 1 Department of Biological Sciences, The University of Bergen, 5007 Bergen, Norway \\ 2 ForestAction Nepal, Lalitpur Kathmandu 12207, Nepal; lilanathsharma@gmail.com \\ * Correspondence: inger.maaren@uib.no; Tel.: +47-4128-5126
}

Received: 23 May 2018; Accepted: 30 July 2018; Published: 4 August 2018

check for updates

\begin{abstract}
Legal protection has been used as means of conserving forests and associated biodiversity in many regions of the world since the eighteenth century. However, most forests in the global south, even those within protected areas, are influenced by human activities. Himalayan forests harbour much of the biodiversity of the region, maintain subsistence livelihoods, and provide regional and global ecosystem services like water regulation, flood control, and carbon sequestration. Yet few studies have quantitatively studied the impacts of legal protection on forest health and biodiversity. We assess woody biodiversity and forest health in relation to legal protection and biomass extraction in forests inside and outside Langtang National Park in Nepal $(n=180)$. We found more woody species in protected forests. Of the 69 woody species recorded, $47 \%$ occurred at both sites. Within protected forests, we found differences in forest health largely related to the intensity of biomass extraction expressed as walking distance to settlement. The closer the forest was to settlements, the heavier degradation it suffered, showing that within agro-forestry systems in the Himalayas, the resource-consumer distance is typically determining the intensity of biomass extraction. Our research brings forth the need to better address the drivers of resource extraction from protected areas in order to mitigate this degradation. It also brings forth the need to contribute to the development of appropriate participatory management programmes outside areas of formal protection in order to sustain both biodiversity and ecosystem service delivery from these forests for the future.
\end{abstract}

Keywords: agroecological systems; biomass harvesting; conservation; ecosystem services; forest health; Langtang National Park; species richness

\section{Introduction}

Domesticated nature, or managed ecosystems, increasingly dominates the earth [1-4] at the cost of natural forest cover. To sustain forest biodiversity most conservation work has focused on the creation of protected areas (PAs). However, approximately $85 \%$ percent of the earth's terrestrial surface is still situated outside formally protected areas, and in the global south, people reside within the boundaries in $70 \%$ of the protected areas $[5,6]$. Consequently, poverty, access rights and environmental degradation are major challenges to biodiversity conservation in the developing world today. Although protected areas will continue to be important for conservation, future conservation efforts will, by necessity, increasingly be focused on areas that have been and continue to be influenced by a manifold of human activities, as protected areas alone are not enough to protect biodiversity in the face of increasing human pressures [7-9]. Increased demand for natural resources due to population growth, the conversion of forest to an alternative permanent non-forested land use such as agriculture, grazing, road construction, or urban development, are leading to forest clearing even around reserves [10] and increased extraction of native species from their local environment [11]. 
The Himalayas has the sharpest terrestrial environmental gradient (in geographical space) on the planet and is situated at the confluence of the Indo-Malayan and the Palearctic realms, making it a biodiversity-rich region, and its forests are some of the richest habitats for plant species $[12,13]$. This diversity is the very basis for rural livelihoods in the Middle Hills of Nepal, as it provides vital ecosystem services such as fuelwood, timber, livestock fodder, and edible, aromatic and medicinal plants, in addition to harbouring important functions like securing water quality and flow regulation, carbon sequestration, erosion control, and regional climate regulation [10,14-18]. Traditional sources of energy including fuelwood, agricultural residues, and animal dung dominate the energy sector in Nepal and constitute $84 \%$ of the total energy consumption (fuelwood alone contributes $75 \%$ ) $[19,20]$, as $83 \%$ of Nepal's population lives in rural areas where fuelwood is the dominant source of energy [21]. Approximately $40 \%$ of the livestock in the Middle Hills is fed with leaf fodder from $c a 100$ tree species [22], and oak species are the most heavily exploited [15,23,24].

Unregulated resource extraction is a major threat faced by many forested areas in Nepal. If the human impact takes on the form of chronic disturbance or extensive logging, forest forming species are not allowed to regenerate [25], resulting in severe forest degradation or deforestation [26-28]. Forest degradation implies a process in which forest stocks decrease without a decrease in area. This is a very common form of chronic disturbance in which biomass removal is 'invisible' on a short time scale but over time it contributes to substantial forest degradation. Major drivers include agricultural expansion, illegal harvesting, lack of clarity in the tenure system, and government resettlement programs [29]. The resulting loss of forest habitat is a major threat to biodiversity conservation, as well as affecting local livelihoods adversely [24,30,31].

The human population in Nepal has increased dramatically from ca 5.6 million in 1911 to 26.5 million in 2011 [21]. This increase, coupled with poverty, political instability, and changes in forest policy, has led to increased pressure on forest resources in recent decades [32]. Typically, poorer households are more reliant on forest resources than wealthier ones, even though the latter may have higher absolute forest incomes [33,34]. Few empirical studies offer a comparison of governance systems in relation to biodiversity and human disturbance in the form of forest biomass harvesting [35]. In this paper, we compare biodiversity conservation success (woody species richness) and forest health (forest structure), in the legally protected forests (PF) inside Langtang National Park with the government managed forests (GF) at Bhalche outside the park. We focus on woody species, as these are the most dominant structures in forest systems and the most important ecosystem service providers to the local communities. The term "protected area" refers to any area of land managed for the persistence of biodiversity and other natural processes in situ through constraints on incompatible land uses [36]. Langtang National Park was established in 1976, and in 1998, a buffer zone was designated. Local communities in the buffer zone receive $30 \%-50 \%$ of the park revenues for better natural resource management. The legal basis for the PF management is the National Parks and Wildlife Conservation Act [37] and its associated regulation and the Himalayan National Park Regulation [38], allowing people within the park to collect fuelwood from dead and fallen logs, branches for cooking and heating purposes, and to extract construction timber by paying a modest royalty [39]. The GF is operated based on the Forest Act of 1993 and the Regulation of 1995, and any person, committee or agency wanting to extract forest products such as timber, fuelwood and NTFPs, for domestic use and for the relief from natural calamities, can get permission from the Authorized Officer by paying a charge. For religious purposes, the supply is free of cost. In practice, local people have de facto right to collect forest products and to graze livestock. We specifically aim to answer (1) under which legal regime is the forest more diverse in terms of woody species richness, (2) how does human disturbance impact forest structure, and (3) what are the most important ecosystem service providers of these forest systems as seen from the local population? 


\section{Materials and Methods}

\subsection{Study Area: Langtang National Park and Associated Forests}

The study was conducted in the Langtang area of Central Nepal (Figure 1). The protected forests (PFs) inside Langtang National Park (LNP) were situated close to former Dhunche and Ramche Village Development Committees (VDCs) (currently Ramche is in Kalika Rural Municipality and Dhunche is in Gosaikunda Rural Municpality) in the Rasuwa district, while the government forests (GFs) were situated in former Bhalche VDC (currently in Kispang Rural Municipality) in the Nuwakot district. Both forested areas are ecologically similar and part of the Trisuli River watershed. LNP $\left(27^{\circ} 57^{\prime} 36^{\prime \prime} \mathrm{N}\right.$ to $28^{\circ} 22^{\prime} 48^{\prime \prime} \mathrm{N}, 85^{\circ} 12^{\prime} 36^{\prime \prime} \mathrm{E}$ to $\left.85^{\circ} 52^{\prime} 48^{\prime \prime} \mathrm{E}\right)$ covers an area of $2130 \mathrm{~km}^{2}$, including buffer zones, with an abrupt altitudinal range (1000 to 7245 meters above sea level; masl), reflected in 18 forest types [40]. Similarly, Nuwakot $\left(27^{\circ} 45^{\prime} \mathrm{N}\right.$ to $28^{\circ} 20^{\prime} \mathrm{N}$ and $85^{\circ} 00^{\prime} \mathrm{E}$ to $\left.85^{\circ} 45^{\prime} \mathrm{E}\right)$ covers an area of $1121 \mathrm{~km}^{2}$ with an elevation range of 540 to 5144 masl [41]. Throughout the Middle Hills (where our study sites are located), the bedrock is dominated by competent phyllites and various degrees of metamorphosed schist with inter-bedding of quartzite, and loams and sandy loams are the most common soil types [42]. Climate is subtropical at lower altitudes and moist temperate at elevations above 2100 masl, characterized as typical monsoon type with warm and wet summers and dry and cool winters, where $80 \%$ of the precipitation falls between June and September. Nagarkot, the nearest climate station at 2163 masl, has an annual rainfall of $1893 \mathrm{~mm}$ (1995-2010) and a mean annual temperature of $11.4{ }^{\circ} \mathrm{C}(2001-2010)$.

In Nuwakot district, agricultural land covers $54 \%$ and forests $32 \%$, of which $26 \%$ is government managed [41]. The studied forests are classified as "low to mid-montane hemi-sclerophyllous broadleaf forest with concentrated summer leaf drop" [43], where the Himalayan oaks dominating this forest type play an important role in maintaining ecosystem integrity. The Langtang area is also home to a number of important wildlife species, including the clouded leopard (Neofelis nebulosa Griffith, 1821), snow leopard (Panthera unica Schreber), musk deer (Moschus chysogaster Hodgson, 1839), the jackal (Canis aereus Linnaeus, 1758), and the red panda (Ailurus fulgens F. Cuvier, 1825), and 15 endemic species of flowering plants, including Rhodondendron cownianum Davidian, $R$. lowndesii Davidian, and Larix nepalensis Hook.f. [40].

The agroecosystems of the study area are highly integrated with forest ecosystems and local people depend upon these forests for fuelwood, timber, fodder collection, litter collection, livestock grazing, medicinal and aromatic plant collection, and hunting to sustain their livelihoods (Table 1). They also provide water quality and flow regulation. Rainfed agriculture is practiced on terraced slopes with two crops per year: one during the rainy season, March-October, and one during the dry season, October-April. Common crops constitute rice, maize, millet, wheat, and potato. Livestock are sustained partly by stall-feeding of leaf fodder collected in the forest mixed with crop by-products and partly by grazing in the forests. Forest leaf litter is used as bedding in the livestock sheds and mixed with animal manure. This forms important natural fertilizer for the cropped fields. Estimates show that four to five hectares of forestland is necessary to maintain soil fertility of one ha of traditionally cropped land [44]. On average, a household in the Middle Hills consumes $334 \mathrm{~kg}$ of fuelwood, $1.49 \mathrm{~m}^{3}$ of timber, $887 \mathrm{~kg}$ of grass, and $863 \mathrm{~kg}$ of leaf litter annually [45]. The ethnic composition of the studied areas of Dhunche, Ranchhe, and Bhalche is chiefly Tamang, which are of Tibetan origin and mainly practice subsistence farming, and Brahmin-kshtrei, Gurungs, and Dalits constitute less than one fifth of population [21]. 

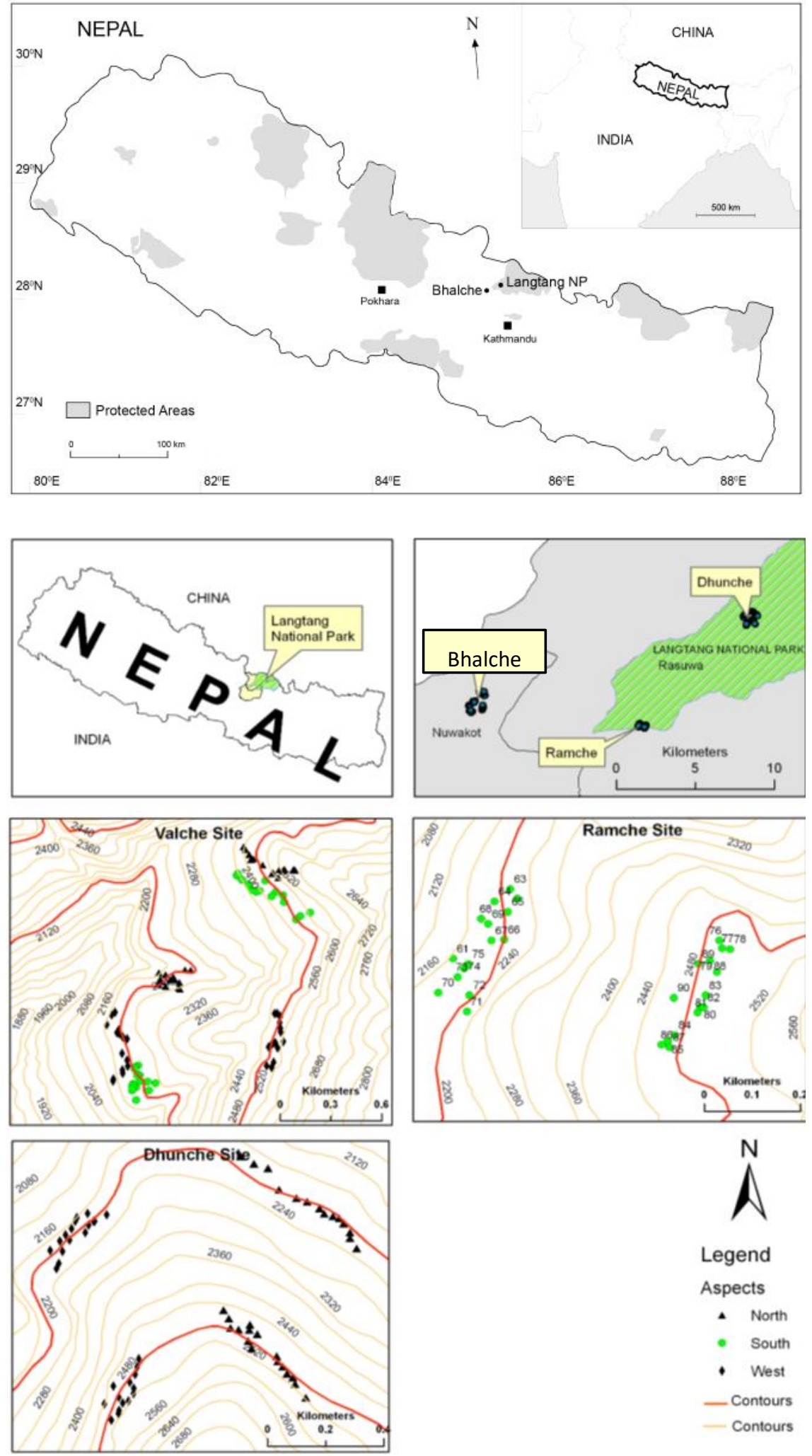

Figure 1. The study areas in Langtang National Park (Rasuwa district: Ramche and Dhunche) and at Bhalche (Nuwakot district) (bottom). Both sites are part of the Trisuli watershed in the Langtang area of Nepal (top). 
Table 1. Characteristics of the two sampled forest areas; inside (Protected Forest) and outside (Government Forest) legal protection in the Langtang area of Nepal. Masl = meters above sea level.

\begin{tabular}{|c|c|c|}
\hline Characteristics & Protected Forest & Government Forest \\
\hline District (population ${ }^{\#}$ ) & Rasuwa $(43,300)$ & Nuwakot $(277,471)$ \\
\hline VDCs (population ${ }^{\#}$ ) & Dhunchhe, Ramche $(2744,2268)$ & Bhalche (3488) \\
\hline Main ethnic composition & Tamang & Tamang \\
\hline Location of settlements (masl) & $1900-2000$ & 1800 \\
\hline Legal designation of the forest & National Park & Government Forest \\
\hline Management responsibility & Department of National Parks and Wildlife Conservation & Department of Forest \\
\hline Access to biomass harvesting & Restricted by park regulations & Open access \\
\hline Fuelwood for cooking (\%) ${ }^{*}$ & 89.8 & 89.6 \\
\hline
\end{tabular}

\subsection{Sampling Design}

Fieldwork (forest analyses and household surveys) was conducted in the pre-monsoon season from March to June 2011. We sampled natural forests and avoided plantations, using a stratified random sampling. Plots were laid out along hillsides at 2200 and 2500 masl. Both forest management types were situated on the same mountain and equal numbers of plots were sampled in each of the types. Results from bulk density, $\mathrm{pH}$ and LOI analyses $(n=60)$ indicate only small differences in soil conditions and we assume the biophysical conditions of the two sampled types to be similar and hence comparable. The $10 \times 10 \mathrm{~m}^{2}$ plots $(0.01 \mathrm{ha})$ were spaced randomly alongside the slope by drawing random numbers, denouncing meters of separation. In total, 180 plots; 90 in the PF and 90 in the GF, were analysed. We excluded plots when (1) steeper than $45^{\circ}$ slope, and thus inaccessible; (2) lacked woody vegetation; (3) contained special habitat types, such as grass-dominated stone outcrops; or (4) contained an established trail. The principal measure of woody species diversity was species richness, defined as the number of woody species present within the 0.01 ha plots, e.g., [46,47]. We included trees (diameter breast height (DBH) at $1.37 \mathrm{~m},>5 \mathrm{~cm}$ ), woody bushes (woody plant with several stems, none dominant, and usually less than $3 \mathrm{~m}$ tall), and woody climbers in this measure. Seedlings (individuals below $1.37 \mathrm{~m}$ of height with no $\mathrm{DBH}$ ) and saplings (DBH $\leq 5 \mathrm{~cm}$ ) of tree species were counted. Species were identified on site by means of standard taxonomic literatures $[48,49]$. All the specimens were photographed and databased in the "Padme database" used to manage information for the Flora of Nepal project. Unidentified plants were collected and later identified at the National Herbarium and Plant Laboratory (KATH) at Godawari, Lalitpur, and Tribhuvan University Central Herbarium (TUCH), Kirtipur. Ocular estimation of overall crown-cover was recorded from the centre of the plot. Cut stumps and coppiced stems were counted. Approximate walking time in minutes from plots to the nearest settlement was recorded. Soil was sampled at a depth of $0-0.3 \mathrm{~m}$ for analysis of $\mathrm{pH}$ in water: suspension (1:2), and organic content by Loss-On-Ignition (LOI) by burning at $550{ }^{\circ} \mathrm{C}$ for $6 \mathrm{~h} \mathrm{[50].}$

Semi-structured interviews were used to solicit information on land-use practices in general, and on forest biomass harvesting in particular. Using a household survey (Table S1), we conducted 44 interviews (24 inside PFs and 20 outside in GFs) with local farmers in the settlements bordering the sampled forests in order to record species utilized and preferred, and to estimate the biomass outtake, as well as record important crops and livestock types. We also asked farmers what they perceive as important forest ecosystem services. We strived to achieve gender, age and ethnic equality by actively choosing to interview young and old, as well as male and female respondents, however, many of the villages were predominantly composed of one or two ethnic groups. The people interviewed ranged in age from 20 to 70 years, with the median of 45 , the gender distribution was $45 / 55 \mathrm{female} / \mathrm{male}$, and Tamangs constituted the ethnic majority (71\%), followed by Gurungs (27\%) and Brahmins (2\%). 


\subsection{Data Analyses}

We analysed forest plot data within and between forests to investigate human impacts on diversity, regeneration and forest health. We considered woody plant richness, regeneration status -seedlings, saplings and mature tree density, and signs of human disturbance in the forests-the number of cut stumps, the number of coppiced individuals, canopy cover and basal area as main variables. We also compared two sampled elevations (2200 and 2500 masl) against variables of stand attributes and human disturbance, as settlements were downslope from forest sites. We used a Shapiro-Wilk test to check normality of the response variables. As our data consisted of count data, it was not normally distributed. We opted for non-parametric tests to compare the regeneration and disturbance between forests. We used Mann-Whitney $U$-test to compare these variables. Generalized Linear Model (GLM) with a log link function was used to test if species richness, regeneration density (density of seedlings, saplings and trees), and human disturbance (number of cut stumps) were affected by the walking distance from the village. A GLM was used because the response variables (species richness, regeneration density, and number of cut stems) represent count data and the error is assumed to have a Poisson distribution. All analyses were performed in R 2.12.2. [51].

\section{Results}

\subsection{Woody Species Richness, Species Composition, and Legal Regime}

We recorded a total of 69 woody species from the forests of Langtang; 65 species inside the Langtang National Park (PF) and 49 species outside the park at Bhalche (GF), of which 33 species were common to both sites. The number of woody species per plot varied, ranging from 7 to 22 , with a mean of 15 in the PF, and from 4 to 19 , with a mean of 11 in the GF. Woody species richness was significantly higher in the PF (Table 2). Within either management category, species richness did not differ between upper and lower elevations (Figure 2). The woody species consisted of 37 species of trees, 19 species of woody bushes and 13 species of woody climbers, none of which are classified as rare, vulnerable or threatened (IUCN; [12]). However, several woody species fall into the near threatened category, e.g., Euonymus pendulus Wall., Daphne bholua Butch.-Ham. Ex. D.Don, Lithocarpus pachyphylla (Kurz.)Rehder., Litsea doshia (D.Don) Kosterm., Eriobotrya elliptica Lindl. and Edgeworthia gardneri (Wall.) Meisn., whereof the latter four were only found within the PF. Out of the 37 tree species, 13 occurred only in the PF, while 4 occurred only at the GF, and 20 species were common to both sites (Figure 3). The five most commonly occurring species in the PF were Lindera pulcherrima (Nees) Hook. f., Quercus semecarpifolia Sm., Lyonia ovalifolia (Wall.) Drude, Rhododendron arboretum Sm. and Quercus glauca Thunb., and in the GF; Symplocos ramosissema Wall. Ex G.Don, Quercus semecarpifolia, Lyonia ovalifolia, Eurya acuminate DC. and Persea duthiei (Hook.f.) Kosterman. (in order of occurrence). Total woody species richness did not show any trend along the measured disturbance indicators (number of cut stumps, number of coppiced trees, and the canopy cover) in either forest. In both the PF and the GF the soils were strongly acidic, with a mean $\mathrm{pH}$ of 4.3 and 4.1, respectively, and with a predominantly sandy loam texture with an average bulk density of $0.48 \mathrm{ton} / \mathrm{m}^{3}$. Walking distance in minutes ranged from 50 to $140 \mathrm{~min}$. (with a mean of 84) in PFs and from 50 to $110 \mathrm{~min}$. (with a mean of 80) in the GFs.

\subsection{Biomass Extraction, Forest Structure, and Regeneration}

The density of cut stumps, a prominent indicator of human disturbance, was double in the GF than that in the PF (Table 2). Within each site, there were more cut stumps at lower elevation closer to settlements, and this gradually declined away from the settlements (Table 3, Figure 4d). The number of coppiced trees did not differ between sites (Table 2) but were substantially higher at lower elevation, irrespective of the legal regime (Table 4). Canopy cover was higher in GFs (ranged between 50 and $90 \%$ with a mean of $77 \%$ ) compared to in the PFs (between 30 and $85 \%$ with a mean of $65 \%$ ). In the GFs, canopy cover did not differ between lower and upper elevation, while in the PFs, it was higher in the upper elevation (Table 4). 
Table 2. Summary statistics for measured variables in forest plots $(0.01 \mathrm{ha})$ inside protected forests (PF) and outside in government forests (GF). Numbers in parenthesis represent median values. $W$ refers to the Wilcoxon $\mathrm{W}$ and is the lowest sum of ranks in Mann-Whitney $U$-test.

\begin{tabular}{ccccc}
\hline Measured Variables & PF & GF & $W$ & $p$ \\
\hline Richness and regeneration & & & & \\
Woody species richness & $15.2(15.0)$ & $10.9(10.5)$ & 1512.5 & $<0.001$ \\
Seedling density & $26.3(25.0)$ & $34.8(27.0)$ & 4441.5 & 0.263 \\
Sapling density & $9.5(8.5)$ & $9.3(8.0)$ & 3984.5 & 0.852 \\
Tree density & $14.7(13.5)$ & $14.5(14.0)$ & 4068.0 & 0.960 \\
\hline Disturbance indicators & & & & \\
Canopy cover (\%) & $64.6(65.0)$ & $76.8(75.0)$ & 5951.5 & $<0.001$ \\
Number of cut stumps & $1.0(0.0)$ & $2.4(1.5)$ & 5367.0 & $<0.001$ \\
Number of coppiced stems & $2.9(2.0)$ & $2.6(2.0)$ & 3854.5 & 0.571 \\
\hline
\end{tabular}

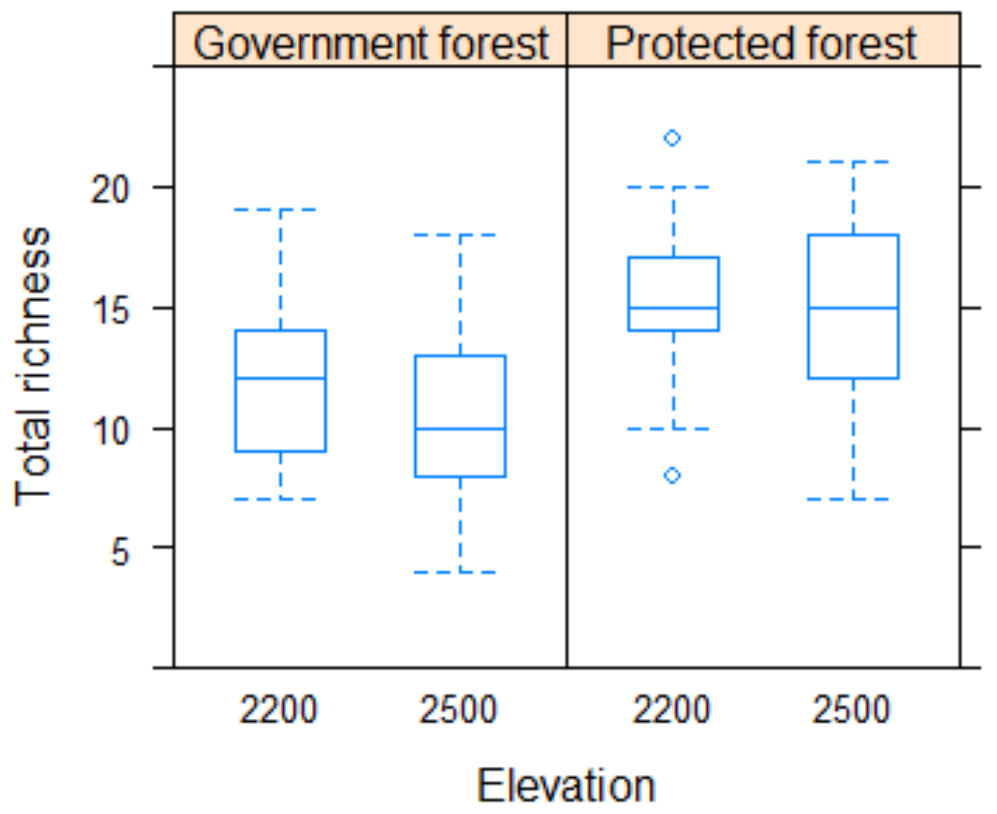

Figure 2. Box-Whisker plots with median (thick line), 25\% and 75\%-quantiles (upper/lower box line) and outliers (circles), showing the comparison of total woody species richness between upper and lower elevation (masl) in government forests (GF) and protected forests (PF) in the Langtang area of Nepal $(n=180)$.

Indicators of forest regeneration (density of trees, saplings and seedlings) showed different trends along the distance from the settlements (Figure 4). Seedling density in both forests gradually increased with distance away from settlement; however, the pattern between the forests differed (Table 5, Figure 4a). Sapling density showed an inverse unimodal response to distance from settlements in PFs, and a linear positive response in GFs (Figure $4 \mathrm{~b}$ ). Tree density showed a gradual decline away from settlements in GFs, while in PFs it did not show any particular pattern (Figure 4c). 


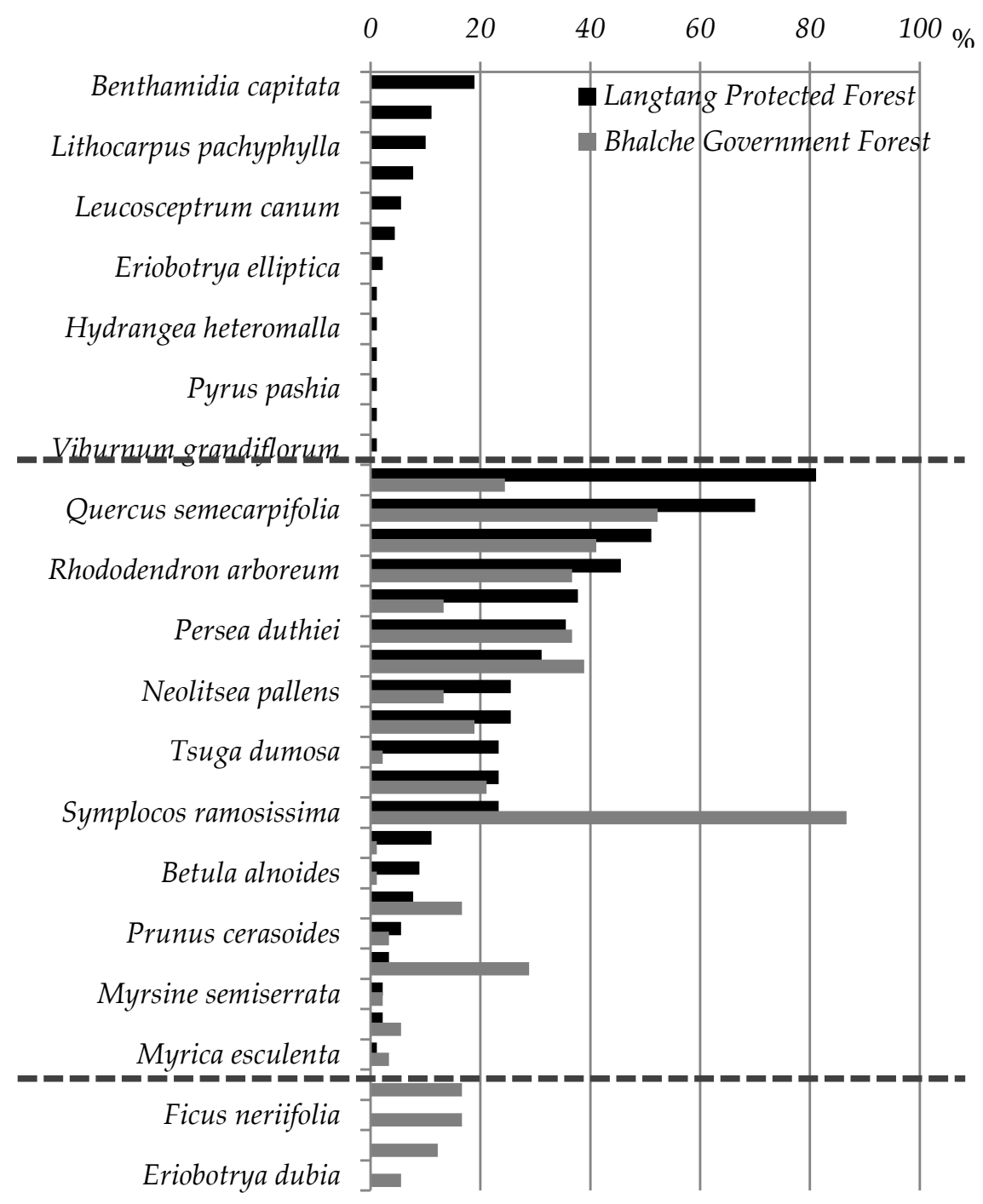

Figure 3. The occurrence of tree species (percent occurrence in the $90 \times 2$ forest plots) in only the Protected Forest ( $\square$ ) (top), both Protected Forest and Government Forest (middle), and only in the Government Forest $(\square)$ (bottom) in temperate broadleaf forests of the Langtang area, part of the Trisuli watershed, Central Nepal $(n=180)$.

Table 3. GLM summary statistics of cut stumps along the walking distance from settlement in protected forests and government forests.

\begin{tabular}{cccccc}
\hline & Deviance & Estimate & $\begin{array}{c}\text { Standard } \\
\text { Error }\end{array}$ & Z value & $\operatorname{Pr}(>|z|)$ \\
\hline Intercept & 184.2 & 2.27980 & 0.40428 & 5.639 \\
Walk distance & 149.15 & -0.02948 & 0.00557 & -5.292 & $1.21 \times 10^{-7 * * *}$ \\
Intercept & 262.64 & 2.82757 & 0.25294 & 11.179 \\
Walk distance & 200.24 & -0.02648 & 0.00355 & -7.456 & $8.95 \times 10^{-14 * * *}$ \\
\hline
\end{tabular}

\# For the null model degrees of freedom (df) was 89 and for the predictor it was 88 . ${ }^{* * *}<0.001$. 


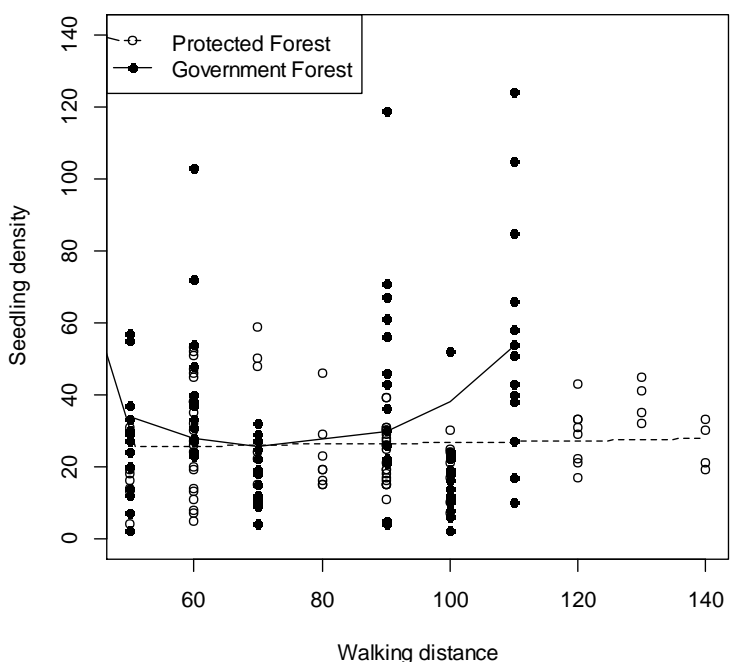

(a)

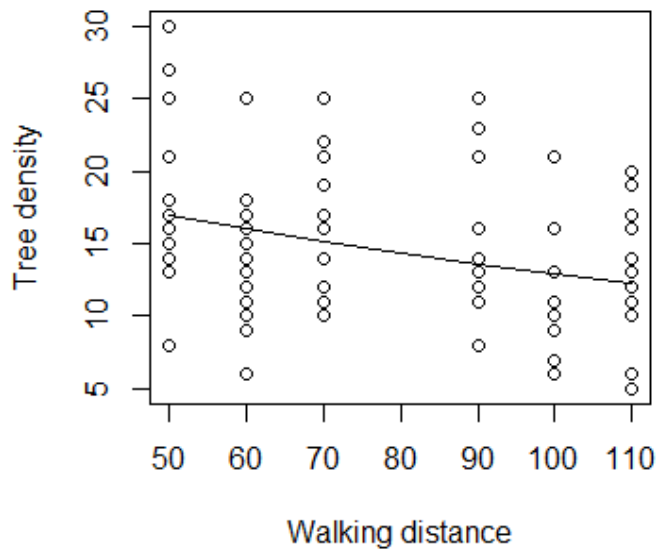

(c)

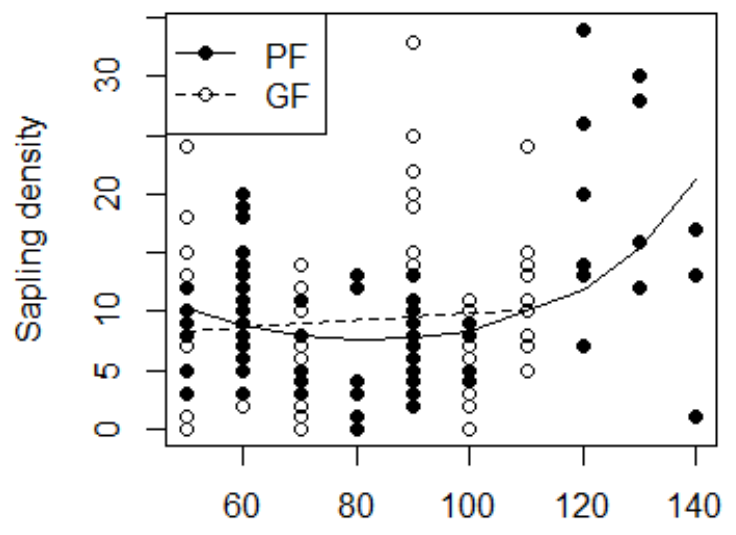

Walking distance

(b)

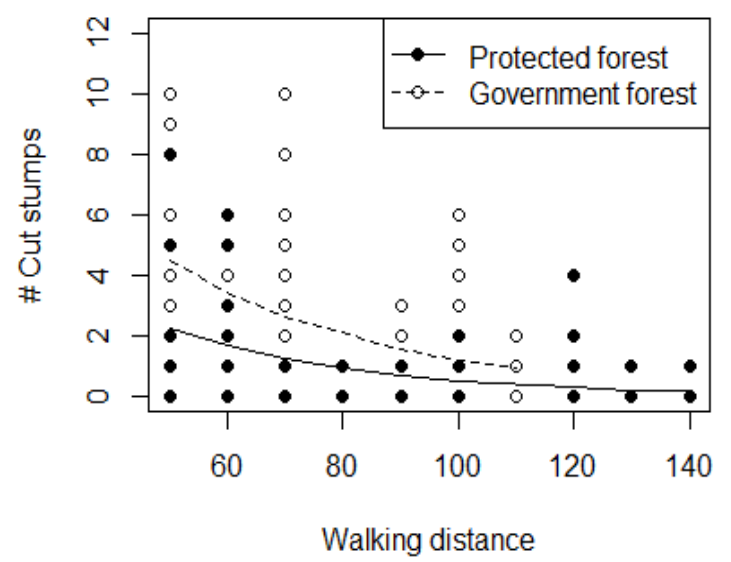

(d)

Figure 4. The relationship between walking distance (in minutes) from closest settlement and (a) seedling density in protected forests (PF) and government forests (GF), (b) sapling density in protected forests and government forests, (c) tree density in government forests, and (d) the number of cut stumps in protected forests and government forests. \# = number of.

\subsection{Forest Ecosystem Services}

Our household survey revealed that many forest species provide important ecosystem services to the adjacent settlements (Figure 5, Table 6) and all households use forests for multiple products. Some of the recorded woody species provide multiple services and may consequently be under higher anthropogenic pressure. Outside and inside the National Park Symplocos ramosissima Wall. ex G.Don, Quercus semecarpifolia, Lyonia ovalifolia, Epatorium odoratum (L.) R.M.King \& H.Rob., and different ferns were preferred as leaf litter to mix in the organic manure. All people interviewed use forests for fuelwood; Symplocos ramosissima, Quercus semecarpifolia, Rhododendron arboretum Sm., Pyrus pashia Buch.-Ham. ex D.Don, Lyonia ovalifolia, and Eurya acuminate were preferred as fuelwood in the GFs, while Rhododendron arboreum, Prunus spp. and Alnus nepalensis D.Don were preferred in the PFs (Table 6). Others collected medicinal plants and wild edible plants, including ferns and mushrooms. 
Table 4. Comparison of means (median) of regeneration and disturbance parameters between two sampled elevations in protected forests (PF) and in government forests (GF) in the Langtang area of Nepal, tested by a Mann-Whitney $U$-test.

\begin{tabular}{ccccc}
\hline Regeneration and Disturbance Parameters & \multicolumn{2}{c}{ PF } & \multicolumn{2}{c}{ GF } \\
\hline Meters above sea level & 2200 & 2500 & 2200 & 2500 \\
\hline Richness and regeneration & & & & \\
\hline Woody species richness & $15.42(15)$ & $15.06(15)$ & $11.5(12)$ & $10.4(10)$ \\
Seedling density & $24.17(20)$ & $28.48(28)^{*}$ & $28.7(27)$ & $40.8(27)$ \\
Sapling density & $9.28(9)$ & $9.77(8)$ & $8.1(7)$ & $10.4(10)$ \\
Tree density & $15.88(14)$ & $13.53(13)$ & $16.04(16)$ & $13.0(12)^{* *}$ \\
\hline Disturbance indicators & & & & \\
\hline Canopy cover (\%) & $60.5(60)$ & $68.8(70)^{* *}$ & $75.9(75)$ & $77.6(80)$ \\
Number of cut stumps & $1.66(1)$ & $0.37(0)^{* * *}$ & $3.7(3)$ & $1.02(0)^{* * *}$ \\
Number of coppiced stems & $3.6(3)$ & $2.2(2) * *$ & $3.3(3)$ & $1.97(2)^{* *}$ \\
\hline
\end{tabular}

Table 5. Generalized Linear Model (GLM) summary statistics of regeneration density and walking distance (walking distance refers to the walking time in minutes from nearest settlement to the forest plots).

\begin{tabular}{|c|c|c|c|c|c|c|}
\hline & Title & Deviance $^{\#}$ & Estimate & Standard Error & $Z$ value & $\operatorname{Pr}(>|z|)$ \\
\hline & Protected forest & & & & & \\
\hline \multirow{3}{*}{ Sapling density } & Intercept & 356.79 & 2.19210 & 0.03601 & 60.877 & \\
\hline & Walk distance, $1 \S$ & 322 & 0.93935 & 0.44170 & 2.127 & 0.0334 * \\
\hline & Walk distance, $2 \S$ & 281.76 & 2.43116 & 0.37661 & 6.455 & $1.08 \times 10^{-10 * * *}$ \\
\hline \multirow{3}{*}{ Tree density } & Government forest & & & & & \\
\hline & Intercept & 155.40 & 3.10225 & 0.10355 & 29.957 & \\
\hline & Walk distance & 137.49 & -0.00543 & 0.00128 & -4.221 & $-2.43 \times 10^{-5 * * *}$ \\
\hline \multirow[t]{3}{*}{ Sapling density } & Intercept & 377.31 & 1.96735 & 0.13543 & 14.526 & \\
\hline & Walk distance & 373.35 & 0.00319 & 0.00160 & 1.988 & 0.0469 * \\
\hline & Intercept & 1798.2 & 3.58285 & 0.01802 & 198.86 & \\
\hline \multirow[t]{2}{*}{ Seedling density } & Walk distance, $1 \S$ & 1690.4 & 4.70613 & 0.32123 & 14.650 & $<2 \times 10^{-16 * * *}$ \\
\hline & Walk distance, $2 \S$ & 1592.8 & 4.23112 & 0.42732 & 9.902 & $<2 \times 10^{-16 * * *}$ \\
\hline
\end{tabular}

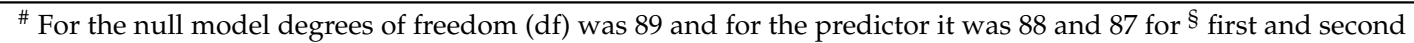
order polynomial regression. ${ }^{*}<0.05,{ }^{* * *}<0.001$.

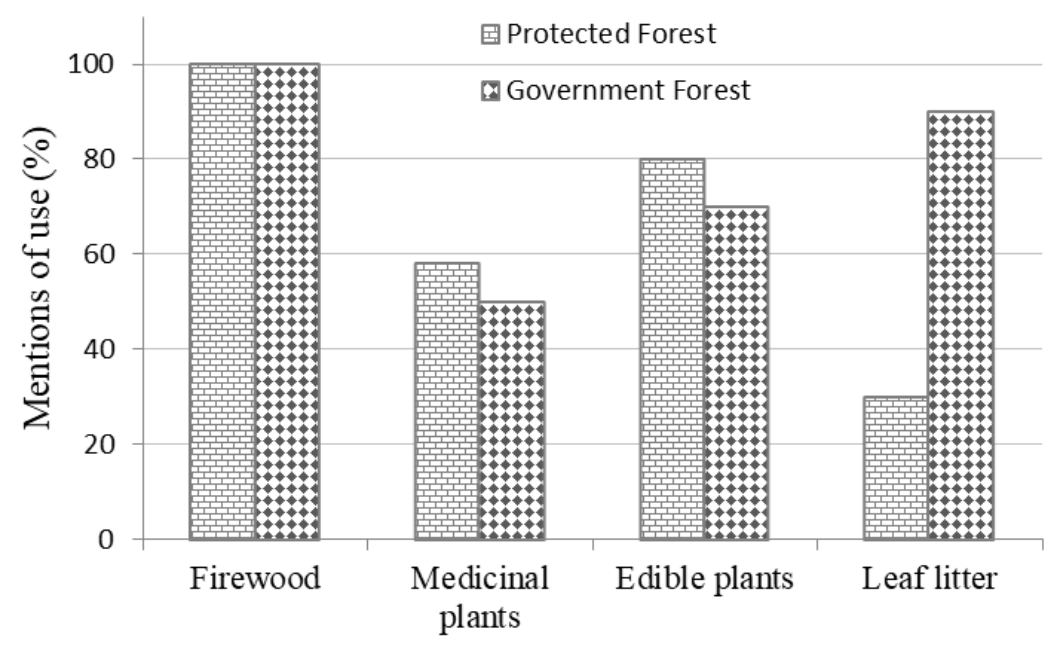

Figure 5. Extraction of forest products from protected forests and government forests, based on household surveys, in the Langtang area of Nepal. 
Table 6. Oversight over commonly used forest species found in protected forests inside Langtang National Park and in government managed forests outside, based on household interviews conducted at the two sites $(n=44)$. Only the five most frequently mentioned species in each category are listed.

\begin{tabular}{|c|c|}
\hline Government Forest & Protected Forest \\
\hline \multicolumn{2}{|c|}{ Fuelwood } \\
\hline Rungeng* & Rhododendron arboreum \\
\hline Eurya acuminate & Prunus spp. \\
\hline Quercus semecarpifolia & Berberis aristata \\
\hline Sungeng * & Quercus semecarpifolia \\
\hline Symplocos ramossisima & Alnus nepalensis \\
\hline \multicolumn{2}{|c|}{ Edible plants } \\
\hline Mushrooms & Mushrooms \\
\hline Dryopteris spp. & Dryopteris spp. \\
\hline Arundinaria spp. (bamboo shoots) & Zanthoxylum armatum \\
\hline Urtica dioca & Arundinaria spp. (bamboo shoots) \\
\hline Myrica esculenta & Urtica dioca \\
\hline \multicolumn{2}{|c|}{ Medicinal plants } \\
\hline Eupatorium adenophora & Swertia chirayita \\
\hline Swertia chirayita & Paris polyphylla \\
\hline Paris polyphylla & Artemisia indica \\
\hline Prasing * & Valeriana jatamansi \\
\hline Khatu * & Gaulhteria fragratissima \\
\hline
\end{tabular}

* Local names.

Seventy-five percent of households at both sites keep livestock. The traditional faming practice is based on the input of organic manure to fertilize the cropped fields and enhance soil quality. All the people at Bhalche (GF) practice agriculture, while in Dhunche and Ranche (PF) the majority of people practice agriculture and a few households have small businesses. Leaf litter is collected for animal bedding, which ultimately turns into compost manure. The difference in legal protection of forest did not make a difference in the type of forest products harvested. Leaf litter was collected at both sites; however, more respondents in the GF reported collecting leaf litter.

\section{Discussion}

\subsection{Species Richness and Forest Management}

We found higher woody species richness inside the protected forests (PFs) than in the adjacent government managed forests (GFs). This is in line with a recent global meta-analysis comparing biodiversity in protected and unprotected areas, clearly showing higher species richness within protected areas [52]. Various case studies also document impoverished floral richness in disturbed/managed forests [53-55]. In contrast to this, a recent review of papers based on European forests [56] reports higher vascular plant species richness in managed forests compared to unmanaged forests. Hence, the picture is mixed; analyses of temporal changes in assemblages suggest no systematic change in plant species richness [57,58], probably due to scale, taxonomic focus, and the degree of human disturbance present in the referenced studies. Additionally, species richness is not the only indicator to compare managed and unmanaged forests, as these can even have similar species richness but differ in beta diversity (species turnover), and high site biodiversity is not necessarily coupled with high site naturalness [59].

Losses of local species richness exceeding $20 \%$ are likely to substantially impair the contribution of biodiversity to ecosystem function and services, and thus to human well-being [60]. In our case, the frequency and density of IUCN listed species were very low under both management regimes [12]. The anthropogenic landscapes of mid-elevation in the Himalayas function as complex agroecosystems, 
where management and conservation need to balance local knowledge, practices and needs by a diversity of local users, and with global aims such as conservation of biodiversity, climate change mitigation and sustainability for future users. A high diversity of woody species is important as it provides a broad resource base for fodder collection throughout the year, as hill farmers have a sophisticated set of criteria for assessing fodder quality in relation to season, livestock type, and qualitative properties [61]. Biodiversity conservation needs to be seen in a broader sense in areas dominated by poverty and social inequity. For instance, Agrawal and Redford [62] found very little systematic evidence in favour of the synergies between biodiversity conservation and poverty alleviation in their survey of 37 studies, and they write, "Glossing biodiversity as 'nature' makes it possible to ignore the complexity of the term, and enables the politically expedient conclusion that humans can use and save 'biodiversity' through easily discovered win-win strategies and solutions". In our case, the lower woody species richness in the un-protected forests reflects higher biomass extraction here.

\subsection{Human Activities and Impacts on Forest Health and Forest Resources}

Human dependency on forests was reflected in the interviews as well as in the forest plot sampling. Under both management regimes, sites more accessible to the nearby settlements were generally more disturbed, and the lower elevation (2200 masl) showed more signs of disturbance, as evidenced by high number of cut stumps, lower canopy cover, and higher numbers of coppiced trees. Overall, canopy cover was higher in the GFs, and this might be a bit puzzling. One reason could be that in the PFs there were smaller trees at the lower elevation and canopy was not closed in many instances, while in the GFs, trees were bigger and the canopy was closed, reflecting use history on a much longer time scale than our study can account for. However, the differences in disturbance had no effect on total woody species richness within the same legal regime (protected or not). Inside the PFs, the forests close to the Ramche and Dhunche settlements were much more degraded, as evidenced by the number of cut stumps and lower canopy cover at the lower elevation, nearby settlements. Coppicing, a "trademark" of disturbed forests of the region, was also higher at lower elevations.

Forests provide a full suite of goods and services that are vital to human wellbeing and livelihoods, particularly in developing countries like Nepal $[15,63]$. The forests of the Trisuli watershed are important and integral parts of the subsistence agro-economy of the region as they are the sources of important forest ecosystem services like fuelwood, fodder, timber, litter (compost), and edible, aromatic, and medicinal plants. Traditional faming practice is based on the input of organic manure to fertilize the cropped fields and enhance soil quality. Our household survey revealed that the extraction or harvesting of biomass from the forest differ between the two sites. This difference is however, reflecting the availability of resources, and not different traditions between these communities.

Human disturbances, including burning, grazing, logging and charcoaling, have large impacts on the seedling, sapling, and shrub layers, which are especially responsive to such disturbances [64]. These disturbances are not uniformly distributed, and tend to be greater in areas with greater accessibility and lower in areas with greater monitoring and enforcement activities, as we also observed in our study. According to a meta-study of 49 locations in 22 countries by Narendra [65], protected areas had significantly lower rates of clearing in comparison to surrounding land. However, the study showed that Asia had the highest rates of land-cover clearing due to lower investments into protected areas, combined with forest depending poor local communities. A study by [66] from the Indian Himalaya, show that changes in land use improved household income, but at the cost of increased extraction of forest biomass and loss of forest cover, undermining sustainable livelihood options and global benefits from the biodiversity and ecosystem services of Himalayan forests.

The sustainability of the hill farming system is contingent upon the management, protection, and utilization of nearby forests. In Nepal, local people's dependency on forest resources was realized soon after designating National Parks in the mountains where people were excluded from forests. People protested and the subsequent Himali National Parks Regulations 2030 [38] allows for local 
people to harvest even from within the National Parks now. Hayes [67] examined whether government ownership of protected areas is a necessary condition for improving forest density but found no statistical difference between forest densities in officially designated protected areas and all other forested areas. Conversely, Gibson et al. found a strong positive correlation between the level of monitoring and foresters' assessments of forest density [68]. Studies by Coleman [69] and Coleman and Steed [70] also found that investment in monitoring by local users was a major variable affecting forest conditions positively. Further, when local users are given harvesting rights, they are more likely to monitor illegal uses themselves [71]. Other studies also stress the relationship between local monitoring and better forest conditions [64,72]. To quote Ostrom and Cox [71] "Thus, it is not the general type of forest governance that is crucial in explaining forest conditions; rather, it is how a particular governance arrangement fits the local ecology and social context, how specific rules are developed and adapted over time, and whether users consider the system to be legitimate and equitable". Nepal, as well as India, has a progressive system of community forestry nationwide in this elevation range [73], and in our case, we also saw some degree of monitoring of illegal uses by local people in both areas.

\subsection{Implications for Management}

The modern concept of ecosystem management grew from the goal of managing regional landscapes to maintain the ecological integrity of the protected areas that they contain [73]. Today, one of the most important developments within conservation science is the recognition that ecological processes cannot be separated from social processes [74]. The very concept of sustainability combines balanced resource use with economic viability, integrating biological, social, and economic aspects at the farm household level [75], and in the case of Nepal, this is in some aspects fulfilled (modest and balanced resource use), while in others (economic viability), this balance is still wanting. Sustainable resource governance requires a sound understanding of social-ecological complexities, and sustainability demands major changes in human behaviour, including in relation to biomass extraction from forests. Meilby et al. in their study from community forests in Nepal found that analyses of sustainability need to recognize the complexity of forest stand utilization and to understand how existing local forest management rules are implemented [76]. Given that human land use is rapidly expanding and intensifying in the unprotected parts of many protected areas (PA) ecosystems, it is critical that we better understand this interplay. With a conservation focus typically focusing on particular habitats, biodiversity conservation in surrounding areas stand the chance of being neglected [77]. Off-PA forests may harbour greater habitat heterogeneity due to various disturbance regimes, supporting a host of species utilizing various successional stages, and may include key livelihood species.

We stress the importance of evidence-based management; a recent paper examining the management of over 1000 PAs in Australia found that managers overwhelmingly tended not to use evidence-based knowledge in making management decisions, but rather they relied almost entirely on knowledge acquired from their own prior experiences [78]. Surprisingly few studies evaluating the success of different forms of nature protection systems actually study the object (s) for which the protection was designed, namely the biological life forms living within its geographic extent, and very few studies relate species diversity directly to forest management and biomass extraction practices (but see [23,79]). Consequently, it is challenging to evaluate the true success of substantial conservation efforts. In locations with human populations that are heavily reliant on local resources, as in our study area in the Trisuli watershed in Nepal (Figure 6), and in much of the biodiversity-rich global south, the foremost management challenge is to promote livelihood alternatives that improves human well-being and reduces overexploitation of forest products and other natural resources. This is perhaps the greatest conservation challenge for the coming decades (see [80]). 


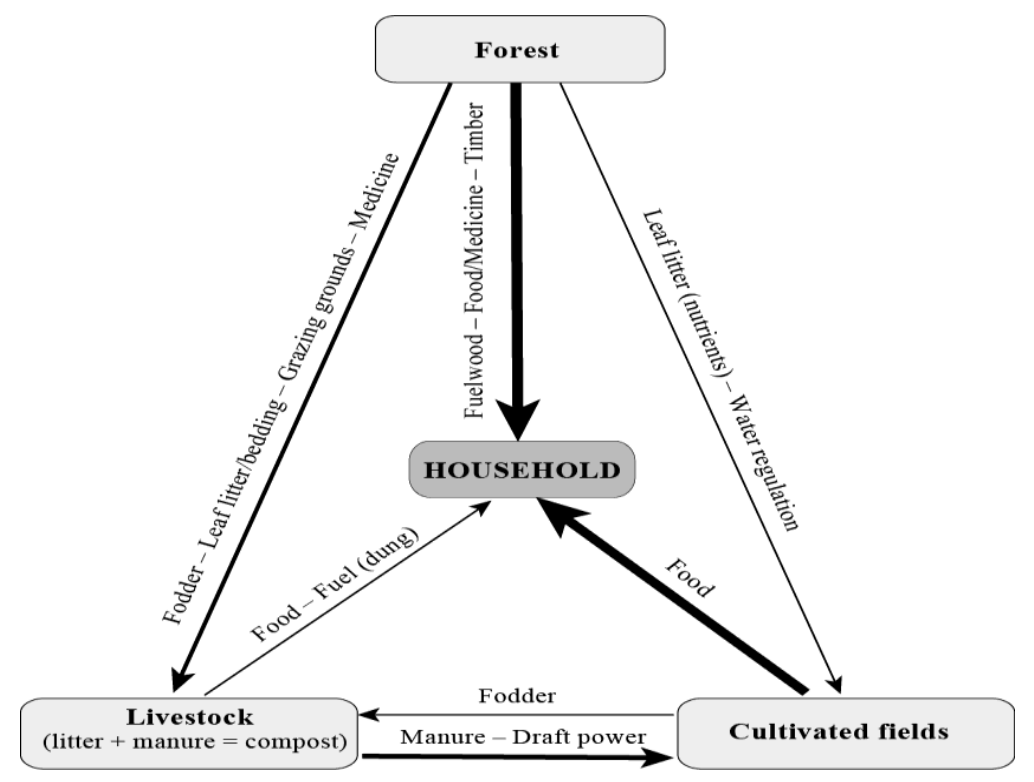

Figure 6. Schematic presentation of interdependencies between the farm household and forests, livestock and cultivated fields. Biomass and nutrients flow from forest to farm household through the traditional system of leaf fodder collection by lopping trees to feed stall fed livestock, and by forest leaf litter collection. Leaf litter and fodder residue are mixed with livestock manure and organic household debris to form a natural fertilizer for enhancing soil quality and crop production.

\section{Conclusions}

Case studies can be very effective in providing in-depth knowledge of particular resource management and conservation issues. In much of Asia there is a great challenge of meeting the objectives of biodiversity conservation and local communities' subsistence needs, and we can only have informed discussions on the trade-offs between forest ecosystem services once we better understand them in the context of the local communities and their environment. Our study is bridging some of this knowledge-gap for the Himalayan context. Irrespective of legal arrangement the investigated forests are exposed to chronic disturbance by subsistence users. This disturbance does not necessarily impair forest regeneration. Returning to our thee original questions we discovered that (1) protected forests were more diverse in terms of woody species richness than government forests, (2) human disturbance in the form of biomass extraction impacts forest structure by reducing structural diversity through coppicing and felling, impairing ecosystem service delivery, and (3) the most important ecosystem service providers are tree species with multiple uses-Primarily timber, fuelwood, and leaf fodder for livestock. We conclude that incorporating both social and ecological knowledge in management decisions is needed for managing forest biodiversity and ecosystem service delivery sustainably.

Supplementary Materials: The following are available online at http:/ /www.mdpi.com/1999-4907/9/8/476/s1, Table S1. Household survey form used to interview farmers in the Trisuli watershed, Langtang area, Nepal.

Author Contributions: I.E.M. conceived and designed the study; L.N.S. carried out the fieldwork; I.E.M. and L.N.S. analysed the data and wrote the paper.

Acknowledgments: Thanks to Bhisnu Chapagain, Asha Suwal, Shreeju Shrestha, and Rajesh Shrestha for field assistance, and to all the villagers and staff members of Langtang National Park who participated. This work is part of the project "Legal frameworks for Conservation of Biodiversity and Ecosystem Services in the Himalayas (HIMALINES)" funded by the Norwegian Research Council (190153/V10) and Grolle Olsens Legat.

Conflicts of Interest: The authors declare no conflict of interest. 


\section{References}

1. Ramankutty, N.; Evan, A.T.; Monfreda, C.; Foley, J.A. Farming the planet: 1. Geographic distribution of global agricultural lands in the year 2000. Glob. Biogeochem. Cycles 2008, 22. [CrossRef]

2. Kareiva, P.; Watts, S.; McDonald, R.; Boucher, T. Domesticated nature: Shaping landscapes and ecosystems for human welfare. Science 2007, 316, 1866-1869. [CrossRef] [PubMed]

3. Ellis, E.C.; Klein, G.K.; Siebert, S.; Lightman, D.; Ramankutty, N. Anthropogenic transformation of the biomes, 1700 to 2000. Glob. Ecol. Biogeogr. 2010, 19, 589-606. [CrossRef]

4. Claire, K. Managing ecosystem services: What do we need to know about their ecology? Ecol. Lett. 2005, 8, 468-479. [CrossRef]

5. The UN Environment World Conservation Monitoring Centre (UNEP-WCMC); International Union for Conservation of Nature (IUCN). Protected Planet Report 2016; UNEP-WCMC: Cambridge, UK; IUCN: Gland, Switzerland, 2016.

6. Terborgh, J.; Peres, C.A. Indigenous People and Protected Areas. In Making Parks Work, Strategies for Preserving Tropical Nature; Terborgh, J., van Schaik, C., Davenport, L., Rao, M., Eds.; Island Press: Washington, DC, USA, 2002.

7. Rodrigues, A.S.L.; Andelman, S.J.; Bakarr, M.I.; Boitani, L.; Brooks, T.M.; Cowling, R.M.; Fishpool, L.D.C.; da Fonseca, G.A.B.; Gaston, K.J.; Hoffmann, M.; et al. Effectiveness of the global protected area network in representing species diversity. Nature 2004, 428, 640-643. [CrossRef] [PubMed]

8. Kareiva, P.; Marvier, M. Conservation Science: Balancing the Needs of People and Nnature; Roberts and Company: Greenwood Village, CO, USA, 2011.

9. Dahal, B.R.; McAlpine, C.A.; Maron, M. Bird conservation values of off-reserve forests in lowland Nepal. For. Ecol. Manag. 2014, 323, 28-38. [CrossRef]

10. Chakravarty, S.; Ghosh, S.K.; Suresh, P.C.; Dey, A.N.; Shukla, G. Deforestation: Causes, Effects and Control Strategies. In Global Perspectives on Sustainable Forest Management; Okia, C.A., Ed.; InTech: Rijeka, Croatia, 2012.

11. Alfredo, E.; Mauro, S.; Miguel, S.; Carlos, G.L. Habitat Mosaic, Wildlife Availability, and Hunting in the Tropical Forest of Calakmul, Mexico. Conserv. Biol. 2000, 14, 1592-1601. [CrossRef]

12. Adhikari, B.; Pendry, C.A.; Måren, I.E.; Bhattarai, K.R.; Chaudhary, R.P. Distribution and preliminary conservation assessments of commonly used forest species in the Nepalese Himalayas. Banko Janakari 2017, 27, 43-54. [CrossRef]

13. Chaudhary, R.P. Biodiversity in Nepal: Status and Conservation; Craftsman Press: Bangkok, Thailand, 1998.

14. MEA (Millennium Ecosystem Assessment). Ecosystems and Human Well-being: Synthesis; Island Press: Washington, DC, USA, 2005.

15. Måren, I.E.; Bhattarai, K.R.; Chaudhary, R.P. Forest ecosystem services and biodiversity in contrasting Himalayan forest management systems. Environ. Conserv. 2014, 41, 73-83. [CrossRef]

16. Price, M.F.; Gratzer, G.; Duguma, L.A.; Kholer, T.; Maselli, D.; Romeo, R. Mountain Forests in A Changing World-Realizing Values, Addressing Challenges; Food and Agriculture Organization of the United Nations (FAO)/MPS and SDC: Rome, Italy, 2011.

17. Suwal, A.L.; Bhuju, D.R.; Måren, I.E. Assessment of forest carbon stocks in the Himalayas: Does legal protection matter? Small-Scale For. 2015, 14, 103-120. [CrossRef]

18. Måren, I.E.; Karki, S.; Prajapati, C.; Yadav, R.K.; Shrestha, B.B. Facing north or south: Does slope aspect impact forest stand characteristics and soil properties in a semiarid trans-Himalayan valley? J. Arid Environ. 2015, 121, 112-123. [CrossRef]

19. Government of India Ministry of Finance. Economic survey 2011-12; Oxford University Press: Uttar Pradesh, India, 2012.

20. Kandel, P.; Chapagain, P.S.; Sharma, L.N.; Vetaas, O.R. Consumption Patterns of Fuelwood in Rural Households of Dolakha District, Nepal: Reflections from Community Forest User Groups. Small-Scale For. 2016, 15, 481-495. [CrossRef]

21. Central Bureau of Statistics (CBS). National Population and Housing Census 2011; Central Bureau of Statistics: Kathmandu, Nepal, 2012.

22. Moench, M.; Bandyopadhyay, J. People-Forest Interaction: A Neglected Parameter in Himalayan Forest Management. Mt. Res. Dev. 1986, 6, 3-16. [CrossRef] 
23. Måren, I.E.; Vetaas, O.R. Does Regulated Land Use Allow Regeneration of Keystone Forest Species in the Annapurna Conservation Area, Central Himalaya. Mt. Res. Dev. 2007, 27, 345-351. [CrossRef]

24. Shrestha, k.B.; Måren, I.E.; Arneberg, E.; Shah, J.P.; Vetaas, O.R. Effect of anthropogenic disturbance on plant species diversity in oak forests in Nepal, Central Himalaya. Int. J. Biodivers. Sci. Ecosyst. Serv. Manag. 2013, 9 , 21-29. [CrossRef]

25. Singh, S.P. Chronic disturbance, a principal cause of environmental degradation in developing countries. Environ. Conserv. 1998, 25, 1-2. [CrossRef]

26. Nagendra, H. Drivers of reforestation in human-dominated forests. Proc. Natl. Acad. Sci. USA 2007, 104, 15218-15223. [CrossRef] [PubMed]

27. Rijal, A.; Meilby, H. Is the life-supporting capacity of forests in the lower Mid-Hills of Nepal threatened? For. Ecol. Manag. 2012, 283, 35-47. [CrossRef]

28. Nagendra, H.; Karmacharya, M.; Karna, B. Evaluating forest management in Nepal: Views across space and time. Ecol. Soc. 2005, 10, 24-39. [CrossRef]

29. Sharma, R.K.; Acharya, B.R. Approach to promoting decentralized land management in Nepal. In Proceedings of the 3rd FIG Regional Conference, Jakarta, Indonesia, 3-7 October 2004.

30. Chaudhary, R.P. Forest conservation and environmental management in Nepal: A review. Biodivers. Conserv. 2000, 9, 1235-1260. [CrossRef]

31. Bhattarai, K.R.; Måren, I.E.; Chaudhary, R.P. Forest ecosystem services; Medicinal plant knowledge of the Panchase region in the Middle Hills of the Nepalese Himalayas. Banko Janakari 2011, 21, 31-39.

32. Baral, N.; Stern, M.J. A comparative study of two community-based conservation models in Nepal. Biodivers. Conserv. 2011, 20, 2407-2426. [CrossRef]

33. Chhetri, B.B.K.; Lund, J.F.; Nielsen, Ø.J. The public finance potential of community forestry in Nepal. Ecol. Econ. 2012, 73, 113-121. [CrossRef]

34. Gautam, A.P. Equity and livelihood in Nepal's community Forestry. Int. J. Soc. For. 2009, 2, 101-122.

35. Paudel, S.; Sah, J.P. Effects of Different Management Practices on Stand Composition and Species Diversity in Subtropical Forests in Nepal: Implications of Community Participation in Biodiversity Conservation. J. Sustain. For. 2015, 34, 738-760. [CrossRef]

36. Possingham, H.; Wilson, K.A.; Andelman, S.J.; Vynne, C.H. Protected areas: Goals, limitations, and design. In Principles of Conservation Biology; Groom, M.J., Meffe, G.K., Carroll, C.R., Eds.; Sinauer Associates, Inc.: Sunderland, MA, USA, 2006; pp. 507-549.

37. Government of Nepal (GoN). National Parks and Wildlife Conservation Act. 1973; Government of Nepal: Kathmandu, Nepal, 1973.

38. Government of Nepal (GoN). Himali National Praks Regulation; Government of Nepal: Kathmandu, Nepal, 1979.

39. Langtang National Park (LNP). Langtang National Park and Bufferzone Management Plan (2009-2014); Department of National Park and Wildlife Conservation (DNPWC): Kathmandu, Nepal, 2008.

40. Bhuju, U.R.; Shakya, P.R.; Basnet, T.B.; Shrestha, S. Nepal Biodiversity Resource Book: Protected Areas, Ramsar Sites and World Heritage Sites; International Centre for Integrated Mountain Development (ICIMO): Kathmandu, Nepal, 2007.

41. Forest Development Plan. Five-Year District Plan (2009 to 2013); District Forest Office: Nuwakot, Nepal, 2009.

42. Carson, B. The Land, the Farmer, and the Future: A Soil Fertility Management Strategy for Nepal; International Centre for Integrated Mountain Development (ICIMOD): Kathmandu, Nepal, 1992.

43. Singh, J.S.; Singh, S.P. Forests of the Himalaya: Structure, Functioning and Impact of Man; Gyanodaya Prakashan: Nainital, India, 1992.

44. Ashish, S.M. Decentralised Management of Natural Resources in the UP Hills. Econ. Political Wkly. 1993, 28, 1793-1796.

45. Sharma, A.J. Impact of Community Forestry on Income Distribution in Nepal. Ph.D. Thesis, Tribhuvan University, Kathmandu, Nepal, 2009.

46. Grime, J.P. Control of species density in herbaceous vegation. J. Environ. Manag. 1973, 1, 151-167.

47. Bhattarai, K.R.; Vetaas, O.R. Variation in plant species richness of different life forms along a subtropical elevation gradient in the Himalayas, east Nepal. Glob. Ecol. Biogeogr. 2003, 12, 327-340. [CrossRef]

48. Polunin, O.; Stainton, A. Flowers of the Himalaya; Oxford University Press: New Delhi, India, 1984.

49. Stainton, A. Flowers of the Himalaya: A Supplement; Oxford University Press: New Delhi, India, 1988.

50. Black, C.A. Methods of Soil Analyses; American Society of Agronomy: Madison, WI, USA, 1965. 
51. Team, R.C. R: A Language and Environment for Statistical Computing; R Foundation for Statistical Computing: Vienna, Austria, 2014.

52. Gray, C.L.; Hill, S.L.L.; Newbold, T.; Hudson, L.N.; Borger, L.; Contu, S.; Hoskins, A.J.; Ferrier, S.; Purvis, A.; Scharlemann, J.P.W. Local biodiversity is higher inside than outside terrestrial protected areas worldwide. Nat. Commun. 2016, 7, 1-7. [CrossRef] [PubMed]

53. Venkateswaran, R.; Parthasarathy, N. Tropical dry evergreen forests on the Coromandel coast of India: Structure, composition and human disturbance. Ecotropica 2003, 9, 45-58.

54. Htun, N.Z.; Mizoue, N.; Yoshida, S. Tree Species Composition and Diversity at Different Levels of Disturbance in Popa Mountain Park, Myanmar. Biotropica 2011, 43, 597-603. [CrossRef]

55. Borah, N.; Athokpam, F.A.; Garkoti, S.C.; Das, A.K.; Hore, D.K. Structural and compositional variations in undisturbed and disturbed tropical forests of Bhuban hills in south Assam, India. Biotropica 2014, 10, 9-19. [CrossRef]

56. Paillet, Y.; Berges, L.; Hjalten, J.; Odor, P.; Avon, C.; Bernhardt-Romermann, M.; Bijlsma, R.J.; De Bruyn, L.; Fuhr, M.; Grandin, U.; et al. Biodiversity Differences between Managed and Unmanaged Forests: Meta-Analysis of Species Richness in Europe. Conserv. Biol. 2010, 24, 101-112. [CrossRef] [PubMed]

57. Dornelas, M.; Gotelli, N.J.; McGill, B.; Shimadzu, H.; Moyes, F.; Sievers, C.; Magurran, A.E. Assemblage Time Series Reveal Biodiversity Change but Not Systematic Loss. Science 2014, 344, 296-299. [CrossRef] [PubMed]

58. Vellend, M.; Baeten, L.; Myers-Smith, I.H.; Elmendorf, S.C.; Beausejour, R.; Brown, C.D.; De Frenne, P.; Verheyen, K.; Wipf, S. Global meta-analysis reveals no net change in local-scale plant biodiversity over time. Proc. Natl. Acad. Sci. USA 2013, 110, 19456-19459. [CrossRef] [PubMed]

59. Maanavilja, L.; Aapala, K.; Haapalehto, T.; Kotiaho, J.S.; Tuittila, E.-S. Impact of drainage and hydrological restoration on vegetation structure in boreal spruce swamp forests. For. Ecol. Manag. 2014, 330, 115-125. [CrossRef]

60. Newbold, T.; Hudson, L.N.; Hill, S.L.L.; Contu, S.; Lysenko, I.; Senior, R.A.; Borger, L.; Bennett, D.J.; Choimes, A.; Collen, B.; et al. Global effects of land use on local terrestrial biodiversity. Nature 2015, 520, 45-50. [CrossRef] [PubMed]

61. Thapa, B.; Walker, D.H.; Sinclair, F.L. Indigenous knowledge of the feeding value of tree fodder. Anim. Feed Sci. Technol. 1997, 67, 97-114. [CrossRef]

62. Agrawal, A.; Redford, K.H. Poverty, Development and Biodiversity Conservation: Shooting in the Dark? Wildlife Conservation Society: New York, NY, USA, 2006.

63. Mahat, T.B.S.; Griffin, D.M.; Shepherd, K.R. Human impact on some forests of the middle hills of Nepal 1. Forestry in the context of the traditional resources of the state. Mt. Res. Dev. 1986, 6, 223-232.

64. Ostrom, E.; Nagendra, H. Insights on linking forests, trees, and people from the air, on the ground, and in the laboratory. Proc. Natl. Acad. Sci. USA 2006, 103, 19224-19231. [CrossRef] [PubMed]

65. Nagendra, H. Do Parks Work? Impact of Protected Areas on Land Cover Clearing. AMBIO: A J. Hum. Environ. 2008, 37, 330-337. [CrossRef]

66. Semwal, R.L.; Nautiyal, S.; Sen, K.K.; Rana, U.; Maikhuri, R.K.; Rao, K.S.; Saxena, K.G. Patterns and ecological implications of agricultural land-use changes: A case study from central Himalaya, India. Agric. Ecosyst. Environ. 2004, 102, 81-92. [CrossRef]

67. Hayes, T.M. Parks, People, and Forest Protection: An Institutional Assessment of the Effectiveness of Protected Areas. World Dev. 2006, 34, 2064-2075. [CrossRef]

68. Gibson, C.C.; Williams, J.T.; Ostrom, E. Local Enforcement and Better Forests. World Dev. 2005, 33, $273-284$. [CrossRef]

69. Coleman, E.A. Institutional factors affecting biophysical outcomes in forest management. J. Policy Anal. Manag. 2009, 28, 122-146. [CrossRef]

70. Coleman, E.A.; Steed, B.C. Monitoring and sanctioning in the commons: An application to forestry. Ecol. Econ. 2009, 68, 2106-2113. [CrossRef]

71. Ostrom, E.; Cox, M. Moving beyond panaceas: A multi-tiered diagnostic approach for social-ecological analysis. Environ. Conserv. 2010, 37, 451-463. [CrossRef]

72. Ghate, R.; Nagendra, H. Role of Monitoring in Institutional Performance: Forest Management in Maharashtra, India. Conserv. Soc. 2005, 3, 509-532.

73. Agrawal, A.; Chhatre, A. Explaining success on the commons: Community forest governance in the Indian Himalaya. World Dev. 2006, 34, 149-166. [CrossRef] 
74. Folke, C.; Gunderson, L. Reconnecting to the biosphere: A social-ecological renaissance. Ecol. Soc. 2012, 17, 55. [CrossRef]

75. Perrings, C.; Duraiappah, A.; Larigauderie, A.; Mooney, H. The Biodiversity and Ecosystem Services Science-Policy Interface. Science 2011, 331, 1139-1140. [CrossRef] [PubMed]

76. Meilby, H.; Smith-Hall, C.; Byg, A.; Larsen, H.O.; Nielsen, Ø.J.; Puri, L.; Rayamajhi, S. Are Forest Incomes Sustainable? Firewood and Timber Extraction and Productivity in Community Managed Forests in Nepal. World Dev. 2014, 64. [CrossRef]

77. Bhagwat, S.A.; Kushalappa, C.G.; Williams, P.H.; Brown, N.D. The role of informal protected areas in maintaining biodiversity in the Western Ghats of India. Ecol. Soc. 2005, 10, 8. [CrossRef]

78. Cook, C.N.; Hockings, M.; Carter, R.W. Conservation in the dark? The information used to support management decisions. Front. Ecol. Environ. 2010, 8, 181-186. [CrossRef]

79. Christensen, M.; Heilmann-Clausen, J. Forest biodiversity gradients and the human impact in Annapurna Conservation Area, Nepal. Biodivers. Conserv. 2009, 18, 2205-2221. [CrossRef]

80. DeFries, R.; Hansen, A.; Turner, B.L.; Reid, R.; Liu, J. Land use change around protected areas: Management to balance human needs and ecological function. Ecol. Appl. 2007, 17, 1031-1038. [CrossRef] [PubMed]

(C) 2018 by the authors. Licensee MDPI, Basel, Switzerland. This article is an open access article distributed under the terms and conditions of the Creative Commons Attribution (CC BY) license (http:/ / creativecommons.org/licenses/by/4.0/). 